\title{
Development of Digital-Based Learning Tools of Research Methodology Course in Early Childhood Teacher Education Department
}

\author{
Aman Simaremare ${ }^{1}$, Roni Sinaga ${ }^{2}$, Santa Murni A. Situmorang ${ }^{3}$ \\ ${ }_{1,2,3}$ Department of Teacher Education for Early Childhood Education, Faculty of Sports Sciences, Universitas \\ Negeri Medan, Indonesia \\ tuansimare@unimed.ac.id,ronisinaga@unimed.ac.id, santasitumorang@unimed.ac.id
}

\section{Abstract}

This study aims to develop digital-based learning tools in a research methodology course. The learning tools that were developed are modules. The development of this module is conducted through the Research and Development Method by Borg \& Gall, the participant involved in the process of developing this learning module consists of material and media design experts, and students who have studied the research methodology course and students who are writing their undergraduate thesis. Data analysis using quantitative descriptive analysis. The final product is made after material and media design expert validation provides recommendations for testing in small groups and large groups. Testing results in the small group obtained an average value of 3.76 (good) and the large group with an average value of 3.70 (good). This indicates that digital-based learning tools in research methodology subject are already worth using. The learning module consists of module: 1. Research concept; 2. Types of research methods; 3. Research problems; 4. Theoretical foundation, thinking framework, and research hypothesis; 5. Research methodology, design, population, and sample; 6. Research data collection techniques and instruments; 7. Research data analysis techniques; 8 . Writing research proposals according to the type of research method; 9. Compilation of research results, discussions, conclusions, and suggestions; and 10. Writing research reports according to the type of research method. The final product of the teaching material module is formatted in $p d f$. This research has limitations, where this research is preliminary so that further development is needed, besides that researchers also experience several obstacles to coordinating with the team directly due to the COVID 19 pandemic, but all are resolved by utilizing internet networks and technology to coordinate. The advantages of the products created make the products created have their own characteristics compared to other products, the modules developed from this research are very relevant to the needs of novice researchers such as students in writing a thesis, on the other side, the modules created are also support students to study online, during the COVID 19 pandemic.
Keywords

digital learning tools; learning modules; R\&D models

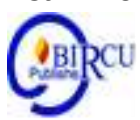

\section{Introduction}

The COVID-19 pandemic has rocked almost all aspects of life including the education sector, with an increase in cases in Indonesia, the government has taken policy steps to 
support efforts to stop the spread of the virus through physical distancing. UNIMED responded to government policy by issuing UNIMED Chancellor's Circular No.000809/UN33/SE/2020 which requires the implementation of online lectures which will be effective on March 17, 2020 and continue to be extended until May 29, 202, the implementation of online learning from home needs to be done with the right approach and optimal use of information technology. The research methodology is a subject that must be taken by PG-PAUD students. Following the national higher education standards, the research methodology course will equip students with competencies in the research field. Students are required to conduct research and produce scientific work, namely a thesis as part of the competence of higher education graduates. Through research methodology, PG-PAUD students are expected to have knowledge and understanding of research methods to complete studies and solve problems in the field of education with a scientific attitude. Through a preliminary study conducted in the even semester of the 2019/2020 school year through FGDs and interviews, it was found that students stated that it was difficult to understand the main material of research methodology optimally, and students who prepared their thesis final project also had difficulty implementing it. The obstacle that causes difficulties for students to attend lectures on this methodology is that the teaching materials in the form of research methodology books are still general in nature.

Digital-based learning tools are considered feasible and appropriate in the online learning process including Research Methodology courses to be developed. Referring to the results of previous research on the development of digital-based learning tools, Ishaq's research states that the development of information and communication technology-based learning can increase the effectiveness of the learning process and student learning outcomes in computer application courses[1].

To answer this problem, it is necessary to carry out similar research on the development of digital-based learning tools that are feasible and effective for use in learning research methodologies in PG-PAUD Study Programs. This study aims to determine the prototype and feasibility of developing digital-based learning tools in the research methodology course. Early Childhood Teacher Education students all this time were experienced difficulties in understanding the research methodology course both theoretically and practically. To assist them to understand the subject matter, digital-based learning tools are developed. These digital-based learning tools is a necessity in learning research methodology course, especially during the COVID 19 pandemic era.

A device is a tool or equipment, whereas learning is an interaction between lecturers and students and learning resources in a learning environment[2], so it can be concluded that the learning device is a tool or device for the interaction process between lecturers and students. and involve learning resources in the learning environment. Lecturers are teachers or those who teach students, lecturers play a role in helping students obtain information, ideas, skills, values, ways of thinking, and means of expressing themselves through learning methods[3]. Learning that can assist students in thinking creatively, solving problems, and

communicating, as well as learning that contributes to the solution of real-world problems, is beneficial (Syakur, 2020).

Digital-based learning devices are the use of the latest technology as tools or equipment in carrying out the learning process or interaction between lecturers and students as well as learning resources in the learning environment. The implementation of digital-based learning will be better because the learning material is richer, it can be in the form of electronic books or electronic articles, learning videos from the internet, virtual reality, and students can easily get them using gadgets and applications that are in their hands. 
Digital activism is a movement / activity in digital media, which is able to organize, accommodate all interests. The use of digital media as a form of identity in a society that has many members or followers. The intended identity is a description of someone, through; physical appearance, characteristics, skin color, language used, self-assessment, and other perception factors, all of which are used in constructing cultural identity (Wahid, 2020).

The role of the media in learning is not in doubt. A number of studies have shown that learning media has a significant effect in increasing motivation or interest, processes or activities, and learning outcomes (Siahaan, 2020). In learning, the media acts as an introduction, facilitates, attracts attention, streamlines time, increases participant involvement, opens space for learning anywhere and anytime, and accelerates and makes it easier to achieve goals. Ideally, the roles of the media have been carried out, but in reality based on the survey results have not been fully realized. In fact, the era of technology, communication and information or the current digital era allows the media to play optimally.

Learning that boils down to mastering complete knowledge and skills, for example learning public speaking, requires appropriate learning media. One of the appropriate learning media fulfilling the above roles is digital media. Digital media or often referred to as new media (new digital media) is an electronic media stored in digital format (as opposed to analog format) which can be used as storage, transmit, and receive digitalized information

The development of digital-based learning tools in research methodology courses is designed with reference to the Regulation of the Minister of National Education, where each level of education in Indonesia refers to the Indonesian National Qualifications Framework.

The educational methodology course is studied in semester VI, with a load of 3 credits. Lectures are held once a week with a total of 16 meetings with theory and practice which are very useful for applying knowledge. Students are given the widest opportunity to develop understanding, analyze with a critical and scientific mindset, and develop skills in research.

The purpose of this course is to produce students who are able to carry out scientific research by analyzing the general basics of scientific research, synthesizing educational research concepts, besides that students are also expected to be able to analyze various types of quantitative research in the field of education.

The process of implementing research methodology lectures is carried out by applying various methods such as lectures, demonstrations, discussions, assignments, presentations, questions and answers, recitation, skills training, problem solving, projects, mind mapping, and debate. The process of implementing lectures is also carried out with theoretical lectures to master the knowledge related to carrying out research and practice to master skills in carrying out procedures in field research.

\section{Research Methods}

This study uses a research design developed by Borg and Gall, the study population was all students of PG PAUD FIP UNIMED who took the research methodology course and the sampling technique by random sampling. Research and development or R\&D methods are research methods used to produce certain products and test the effectiveness of these products (Sugiyono in Damanik, 2020). The data was collected using an interview instrument, a value scale, and a checklist.

The subjects involved in the process of developing this learning module device consisted of material experts, design experts, lecturers who taught research methodology courses and students who had taken research methodology courses and students who were writing their thesis final project. Interviews were conducted in a preliminary study, including interviews with lecturers who taught research methodology courses and students who had 
taken research methodology courses and students who were writing their thesis final project. The interview aims to gather information about the needs and constraints that occur in the learning process of the research methodology. The value scale is used during the validation test by material experts and media experts on the research methodology learning tools, as well as the research methodology learning achievements of students in small and large group trials. The data collection instrument is in the form of a validation sheet given to material experts and media experts, to assess the feasibility of the content including the suitability of the material, the accuracy of the material, supporting learning materials, the updating of the material; aspects of the feasibility of presentation include: presentation techniques, support for presentation, presentation of learning, and completeness of presentation; linguistic aspects include: straightforward, communicative, dialogic and interactive, conformity to the level of student development, coherence and integration of thought lines, and use of terms or symbols. The data from the validation results will also become a reference for revision until it is declared feasible to be tested.

The data analysis technique used a quantitative descriptive analysis technique approach. Descriptive analysis was carried out to present data related to the development of digitalbased learning tools in the research methodology course, which aims to make it easier to interpret data.

\section{Discussions}

The learning tools developed for the research methodology course are in the form of learning modules which are carried out through the stages of analyzing the potential and problems of the research object. The potential of human resources in this research is having four lecturers who are experienced in teaching research methodology courses as well as professors as experts in the field of science who have produced book writing works that can be used as a reference source for validating module content, in addition to supporting facilities in the form of a digital library, which can support the learning process and provide reference sources that can be accessed by students and lecturers so that it allows for the preparation of learning modules. In addition to this potential, there are also problems, namely teaching materials which are the work of lecturers, especially in research methodology courses which are more practical and easily adopted by students, are not yet available and the available books are still incomplete as a reference source and to meet the learning needs of research methodology Furthermore, the information collection stage was carried out in the even semester of the 2019/2020 academic year through FGDs and interviews, the information obtained from the results of the FGD and interviews showed that students stated that it was difficult to understand the subject matter of the research methodology subject optimally, and students who compiled their thesis final project also experienced difficulties in implementing it.

Based on the results of the analysis of the initial conditions of the resulting learning module, it is more practical and refers to the semester learning plan, then validates the design. Design validation is carried out through discussion of the writing team with experts who are experienced in writing textbooks and assessing textbooks to find out the weaknesses and strengths of the product so that there are some notes of improvement. The design improvement shows that there is a change in the contents of the module, which previously amounted to 11 modules to 10 because there are modules that should only be combined because they have similarities in their studies. Before the module is tested, the initial stage is to collect data using instruments or a questionnaire given to two experts, the average value of the expert trial results is; Content eligibility (2.76), service eligibility (2.96), and linguistic aspect (2.81) with enough categories. The module compiled is not feasible so it needs to be 
revised. Module testing after repair is continued with limited product testing, the average value of the test is; Content eligibility $(3,67)$, service eligibility $(3,78)$, linguistic aspect $(3,83)$ with good categories.

After going through a limited product trial, a large group trial was carried out on students whose characteristics were the same as during the limited trial, namely students who had taken research methodology courses in the last semester and also to students who were writing proposals or research thesis the average value of the large group product trials results is; Content eligibility (3.58), service eligibility (3.73), linguistic aspect (3.74) with good categories, so no more revisions are made to the learning module products that will be used.

\section{Conclusion}

Based on the results of the study, it can be concluded that the development of learning tools for research methodology courses developed in the form of learning modules contains: modules 1. Basic Concepts of Research Methodology, modules 2. Types of Research, modules 3. Problem Formulations, Modules 4. Theoretical Frameworks, framework of Thinking, and Hypotheses, Module 5. Methods, Design, Population and Research Samples, Module 6. Techniques and Instruments Data Collection, Module 7. Data Analysis Techniques in Research, Module 8. Research Results, Discussion of Conclusions and Research Suggestions, Module 9. Preparation and Format of Research Reports, Module 10. Research Reports.

\section{References}

B. Joyce and M. Weil, "Conceptual Complexity, Teaching Style and Models of Teaching," Internasional, 1972.

Direktorat Jendral Pembelajaran dan Kemahasiswaan Ristek Dikti, Panduan Penyusunan Kurikulum Pendidikan Tinggi di Era Industri 4.0, 3rd ed. Jakarta: Direktorat Jenderal Pembelajaran dan Kemahasiswaan Kementerian Riset Teknologi dan Pendidikan Tinggi, 2019.

Ishaq, "Desain Pengembangan Pembelajaran Design Development Based Learning Information And Communication Technology ( ICT )," Jpf, vol. I, no. 3, pp. 73-85, 2018.

Permendikbud No.49 Tahun 2014, Standar Nasional Pendidikan Tinggi. Jakarta, 2014.

Syakur, A. Et.al (2020). The Effect of Project-Based Learning (PjBL) Continuing Learning Innovation on Learning Outcomes of English in Higher Education. Budapest1International Researchand1Critics in1Linguistics and1Education (BirLE)1Journal Vol 3 (1): 625-630.

W. R. Gall, M. D., Gall, J. P., \& Borg, Educational research: An introduction (7th ed.). 2003.

Wahid, R., Pribadi, F., and Wakas, B.E. (2020). Digital Activism: Covid-19 Effects in Campus Learning. Budapest International Research and Critics in Linguistics and Education (BirLE) Journal Vol 3 (3): 1336-1342.

Siahaan, R.Y.K.P., Daulay, S., and Hadi, W. (2020). The Effectiveness of Public Speaking Learning Media Based on Digital Multimodal in Indonesian Language Courses at Politeknik Pariwisata Medan. Budapest International Research and Critics in Linguistics and Education (BirLE) Journal Vol 3 (4): 2036-2047. 